\title{
Copper deficiency and effects of copper supplementation in a herd of red deer (Cervus elaphus) Kjell Handeland*1, Aksel Bernhoft ${ }^{2}$ and Magne S Aartun ${ }^{3}$
}

\author{
Address: ${ }^{1}$ Section for Wildlife Diseases, National Veterinary Institute, P.O. Box 8156 Dep., 0033 Oslo, Norway, ${ }^{2}$ Section for Toxicology, National \\ Veterinary Institute, P.O. Box 8156 Dep., 0033 Oslo, Norway and ${ }^{3}$ Lillesand Veterinary Office, Ringgata 22A, 4790 Lillesand, Norway \\ Email: Kjell Handeland* - kjell.handeland@vetinst.no; Aksel Bernhoft - aksel.bernhoft@vetinst.no; \\ Magne S Aartun - dyreklinikken@lillesand.online.no \\ * Corresponding author
}

\section{Published: 30 April 2008}

Acta Veterinaria Scandinavica 2008, 50:8 doi:10.1186/175I-0147-50-8

This article is available from: http://www.actavetscand.com/content/50/I/8

(c) 2008 Handeland et al; licensee BioMed Central Ltd.

This is an Open Access article distributed under the terms of the Creative Commons Attribution License (http://creativecommons.org/licenses/by/2.0), which permits unrestricted use, distribution, and reproduction in any medium, provided the original work is properly cited.
Received: 15 February 2008

Accepted: 30 April 2008

\begin{abstract}
Copper ( $\mathrm{Cu}$ ) deficiency was diagnosed in a Norwegian red deer (Cervus elaphus) herd subsequent to deaths due to emaciation in late autumn 1999. The animals had free access to salt licks containing $3000 \mathrm{mg} \mathrm{Cu} / \mathrm{kg}$. An evaluation of the herd revealed poor calf growth rate, low weights of adult hinds, dull and light-coloured hair coats and cases of diarrhoea. The herd was subsequently monitored throughout a three-year period of Cu-supplementation. The monitoring regimen included clinical observation, copper serum examination, weighing, faecal parasitological examination, and reproduction control by ultrasound. During the period January 2000 to May 200 I, the animals were treated with $\mathrm{Cu}$ oxid capsules ( $\mathrm{g} \mathrm{g} \mathrm{CuO} / \mathrm{l} 0 \mathrm{~kg}$ liveweight) at $2-4$ months intervals, with the exception of March to September 2000. The animals were fed continuously with $\mathrm{Cu}$ enriched concentrates containing $300 \mathrm{mg} \mathrm{Cu} / \mathrm{kg}$, at a rate of $\mathrm{I} / 2 \mathrm{~kg}$ per head and day, from May $200 \mathrm{I}$ to January 2003. Following both copper supplementation regimens adequate serum $\mathrm{Cu}$ concentrations were measured, and markedly improved body weights, coat quality and reproductive results were observed, except for the period from March to September 2000 when no treatment was given. The results showed that in a deer herd, with a diet low in $\mathrm{Cu}$, supplementation with $\mathrm{CuO}$ capsules had to be given at intervals of a few months to maintain adequate serum $\mathrm{Cu}$ levels. Free access to $\mathrm{Cu}$-containing salt licks did not meet the animals' $\mathrm{Cu}$ demand. Good and stable results were achieved by the daily feeding of $\mathrm{Cu}$-enriched concentrates.
\end{abstract}

\section{Findings}

Copper $(\mathrm{Cu})$ deficiency causes various disease syndromes in ruminants [1]. In farmed red deer (Cervus elaphus), deficiency has been associated with general unthrift, recognized as poor body condition, growth rates and coats [2$5]$, as well as enzootic ataxia $[6,7]$ and osteochondrosis $[8,9]$. Another trace element deficiency observed in farmed deer is selenium (Se) deficiency, causing nutritional myopathy and Se responsive ill-thrift $[10,11]$. Clinical signs of $\mathrm{Cu}$ or Se deficiency have not been recorded in free-ranging red deer although low levels of both elements have been found in Norwegian populations [12]. This study presents clinical, chemical and reproductive data in a Cu-deficient Norwegian red deer herd that was diagnosed in late autumn 1999, and subsequently followed up throughout a three-year period of Cu-supplementation.

The herd was established in 1995, and consisted of approximately 15 adult hinds with additional calves and 
yearlings. The animals were kept in a 20 hectare enclosure consisting of permanent grazing land and deciduous forest. In summer, they also grazed cultivated ryegrass and white clover fields. During winter the herd was fed baled grass silage ad libitum and concentrates produced for dairy cows (105 neutral, Felleskjøpet, Norway) containing $20 \mathrm{mg} \mathrm{Cu}$ per $\mathrm{kg}$, a ration of $1 / 2 \mathrm{~kg}$ per head per day. The animals also had free access to salt licks (KNZ Vilt, Felleskjøpet, Norway), containing $3000 \mathrm{mg} \mathrm{Cu} / \mathrm{kg}$. The herd was dewormed in the spring and autumn, using Ivomec pour-on vet. ${ }^{\oplus}$ (Merial SAS, Lyon, France). The normal mating period was October with births in late May to early June.

During late autumn 1999, generally thin and unthrifty animals with dull light-coloured hair coats and cases of diarrhoea were observed. Three adult hinds died in an emaciated condition. Two of them were necropsied in the field. The third hind was necropsied in the laboratory, following standard procedures. Samples from the brain, spinal cord, lungs, heart, liver and kidneys were fixed in $10 \%$ buffered formalin, and processed routinely for histological examination. Standard bacteriological examination on calf blood agar plates was performed on samples of lung, liver and intestinal content. Additionally, specific bacteriological examination for Mycobacterium avium subspecies paratuberculosis was carried out on the intestinal content, and on jejunal and ileocaecal lymph nodes [13]. At necropsy, the hind was cachectic and weighed $60 \mathrm{~kg}$. Other pathological findings included a moderate verminous pneumonia caused by Dictyocaulus sp., and fluid contents throughout the intestinal canal. No histopathological lesions were found in the organs, and all bacteriological examinations were negative with regard to pathogenic bacteria. Chemical examination of liver tis- sue from the carcass revealed $\mathrm{Cu}$ and Se concentrations of $1.8 \mu \mathrm{g} / \mathrm{g}$ and $0.15 \mu \mathrm{g} / \mathrm{g}$ wet weight (ww) respectively. In succession to these findings, three yearling stags were slaughtered, and their mean liver concentrations of $\mathrm{Cu}$ and Se were determined to be $2.4 \mu \mathrm{g} / \mathrm{g}(2.0-3.2)$ and 0.24 $\mu \mathrm{g} / \mathrm{g}(0.21-0.27)$ respectively. The analyses were principally performed as described previously [14]. In farmed deer, $\mathrm{Cu}$ concentrations in the liver $<4 \mu \mathrm{g} / \mathrm{g}$ wet weight (ww) and serum concentrations $<0.3 \mu \mathrm{g} / \mathrm{ml}$ are considered to represent deficiency [5], whereas a deficiency level of Se has not been defined.

In the subsequent study period from January 2000 to January 2003, the animals were mechanically immobilized for blood (serum) sampling, weighing and Cu-supplementation at various time points (Table 1). Serum samples were obtained from all age classes and at least $75 \%$ of the animals in the herd, and the mean herd serum concentration of $\mathrm{Cu}$ was calculated for each sampling. The mean weights of calves and adult hinds were calculated separately for each weighing. During the period January 2000 to May 2001, the animals were treated with $\mathrm{Cu}$ six times. On five of these occasions they were administrated capsules containing $2.5 \mathrm{~g} \mathrm{Cu}$ oxide, one capsule per $25 \mathrm{~kg}$ liveweight $(1 \mathrm{~g} / 10 \mathrm{~kg})$. On the sixth occasion, they were treated with calcium copper edetate given subcutaneously at doses of $50 \mathrm{mg}$ for calves, and $100 \mathrm{mg}$ for yearlings and adults. From May 2001 to January 2003, the animals were fed continuously with Cu-enriched concentrates $(300 \mathrm{mg}$ $\mathrm{Cu} / \mathrm{kg}$ ) produced for deer (Tilskuddfôr Hjort, Felleskjøpet, Norway), a ration of $1 / 2 \mathrm{~kg}$ per head and day. The winter-feeding of concentrates produced for dairy cows ceased after starting Cu-enriched concentrates. Pregnancy of hinds $>2$ years was determined by ultrasound in January 2000, 2001, 2002 and 2003. Faecal samples for para-

Table I: Copper status in a red deer herd. Mean and range of serum copper $(\mu \mathrm{g} / \mathrm{ml})$, mean and range of live weights (kg) of adult hinds and calves, and copper administration; by month 2000 to 2003.

\begin{tabular}{|c|c|c|c|c|}
\hline Month & Serum copper [Range] & Weights of adult hinds [Range] & Weights of calves [Range] & Copper administration \\
\hline January 2000 & $0.31(\mathrm{~N}=23)[<0.10-0.86]$ & $82(N=12)[67-94]$ & $38(N=7)[27-45]$ & $x^{\prime}$ \\
\hline March 2000 & $0.84(\mathrm{~N}=27)[0.30-1.10]$ & & & $x^{2}$ \\
\hline April 2000 & & $90(N=13)[70-102]$ & $48(\mathrm{~N}=7)[42-55]$ & \\
\hline May 2000 & $0.92(\mathrm{~N}=23)[0.66-1.20]$ & & & \\
\hline September 2000 & $0.25(\mathrm{~N}=20)[<0.10-0.62]$ & & & $x^{\prime}$ \\
\hline November 2000 & & & & $x^{\prime}$ \\
\hline January 2001 & $0.91(\mathrm{~N}=19)[0.30-2.00]$ & $92(\mathrm{~N}=14)[72-102]$ & $40(\mathrm{~N}=3)[38-45]$ & $x^{\prime}$ \\
\hline May 2001 & & & & $x^{1,3}$ \\
\hline September 2001 & $1.08(\mathrm{~N}=24)[0.70-1.66]$ & & & $x^{3}$ \\
\hline January 2002 & $0.77(\mathrm{~N}=12)[0.61-0.99]$ & $108(N=12)[94-126]$ & $53(\mathrm{~N}=8)[5 \mathrm{I}-58]$ & $x^{3}$ \\
\hline May 2002 & $1.11(N=21)[0.78-1.60]$ & & & $x^{3}$ \\
\hline September 2002 & $1.00(\mathrm{~N}=26)[0.34-1.50]$ & & & $x^{3}$ \\
\hline January 2003 & & $104(N=16)[8 \mid-120]$ & $64(N=10)[57-74]$ & $x^{3}$ \\
\hline
\end{tabular}

$x^{\prime}$ Copper capsules; Copacaps ${ }^{\circledR}$, Rhône Merieux Limitid, Harlow, Essex, UK.

$\mathrm{x}^{2}$ Copper injectable; Coprin ${ }^{\circledR}$, Mallinckrodt Veterinary Ltd, Breakspear Road South, Harefield, Middlesex, UK

$\mathrm{x}^{3}$ From May $200 \mathrm{I}$ the herd was fed continuously with concentrates containing $300 \mathrm{mg} \mathrm{Cu}$ per kg, I/2 kg per head per day 
sitological examination were collected quarterly throughout the years 1999-2002, each sampling including 4-8 animals from different age groups. The samples were analysed for parasite eggs and oocysts using sugar flotation, and for lungworm larvae after baermannisation.

The mean serum $\mathrm{Cu}$ concentrations of the animals in the herd at different time points from January 2000 to September 2002 are summarized in Table 1 . The Cu concentration increased from a low level in January 2000 to an adequate level in March and May following the Cu-treatment in January and March. The mean serum Cu concentration, with no additional $\mathrm{Cu}$ treatments, again fell to a low level by September 2000. Levels returned to normal by January 2001 after Cu-treatment in September and November 2000. Following treatment in January and May 2001, and the daily feeding of Cu-enriched concentrates from May 2001, the mean serum $\mathrm{Cu}$ concentration of the herd appeared adequate when measured in September 2001, and in May and September 2002.

In January 2000, the weights of adult hinds and calves (Table 1) were low and ultrasound scans revealed only $23 \%$ as pregnant. Following $\mathrm{Cu}$ treatment in January and March 2000, markedly bettered body condition and hair coat of the animals were observed. The weight gain in adult hinds and calves from January to April 2000 was $10 \%$ and $26 \%$ respectively. Another remarkable feature that occurred following this $\mathrm{Cu}$ treatment was that several hinds came into oestrus out of season and were covered, resulting in calving in November and December 2000. Two fully developed newborn calves were found dead in the enclosure whilst a third calf was found alive in the moribund state. The weight gain of the animals during summer 2000 was, in spite of good grazing conditions on luxuriant cultivated pasture, not satisfactory and the mean weights of calves and adult hinds in January 2001 were only $5 \%$ and $11 \%$ respectively higher than those seen in January 2000. The percentage of hinds found to be pregnant in January 2001 was $46 \%$. During the summers of 2001 and 2002 the weight gain in the herd was good, and the mean weights of calves and adult hinds in January 2002 and 2003 were 59\% and $29 \%$ respectively above the level in January 2000. The reproductive success also improved remarkably, with $90 \%$ of hinds scanned in January 2002 and 2003 being pregnant. Faecal parasitological examinations of the animals in the herd revealed only low to moderate counts of parasite eggs and oocysts, and of lungworm larvae.

The findings in the herein reported red deer were consistent with unthrift related to a general Cu-deficiency in the herd, as reported in other studies [2-5]. Whether this deficiency was a result of an inadequate concentration of $\mathrm{Cu}$ in the diet (primary deficiency), or a result of dietary excess of antagonists (Mo, $\mathrm{Fe}, \mathrm{Zn}, \mathrm{S})$, interfering with the utilization of $\mathrm{Cu}$ (secondary deficiency) [1], could not be determined. Specific syndromes of disease, i.e. enzootic ataxia and osteochondrosis, that have previously been reported in Cu-deficient red deer herds in Norway $[9,15]$, were not observed. Whether the cases of diarrhoea seen in the present study were related to $\mathrm{Cu}$-defiency remains an open question. However, diarrhoea of uncertain pathogenesis has been associated with Cu-deficiency in domestic ruminants [1].

The low rate of pregnancy observed in January 2000 was presumably an indirect effect of Cu deficiency, linked to the low body weights of hinds. No evidence of reproductive failure associated with specific $\mathrm{Cu}$-mechanisms has been reported in domestic ruminants [1], and good nutritional status of deer hinds prior to mating is essential to achieve not only high fertility but also a concentrated calving season [16]. The Cu supplementation that was carried out in January and March 2000 resulted in general weight gain of hinds, and conception of several hinds in late spring, which is highly unusual. Other results of $\mathrm{Cu}$ supplementation seen in the present study included growth response in calves, and improved coat quality. These are all well known effects reported in several studies of $\mathrm{Cu}$ supplementation in deficient deer herds [3-5].

The liver concentrations of Se found in the red deer in the present study were above the minimum concentration considered to be adequate in domestic ruminants [1]. However, there are strong indications that both $\mathrm{Cu}$ and $\mathrm{Se}$ are trace elements of concern in Norwegian red deer farming. Deficiencies or marginal concentrations of both elements have been found in many farms having submitted liver samples for the control of trace element status to the National Veterinary Institute, and have also been demonstrated in fallow deer (Dama dama), moufflon (Ovis aries musimon) and moose (Alces alces) held in parks in this country (Unpublished data).

In the present study, the oral treatment with $\mathrm{CuO}$ capsules increased the $\mathrm{Cu}$ concentration in serum to within adequate levels, but only for a relatively short time-period. Between March and September 2000, when no capsules were given, the serum $\mathrm{Cu}$ concentration again dropped to inadequate levels. This should also be seen in connection with the use of cultivated grass pastures during summer; rapidly-growing grass is known to be poor in $\mathrm{Cu}$ [17]. This drop in serum $\mathrm{Cu}$ concentration during the main period of growth and weight gain over the summer presumably contributed to the low body weights found in January 2001. For maintenance of adequate serum levels with a diet low in $\mathrm{Cu}$, it seemed that $\mathrm{CuO}$ capsules need to be given at intervals of a few months. This is in accordance with observations reported in other studies $[3,18,19]$. The 
free access of the herd to Cu-containing salt licks obviously did not meet the animals' $\mathrm{Cu}$ demand. Good and stable results were achieved by the daily feeding of $\mathrm{Cu}$ enriched concentrates, used during the second part of this study.

\section{Competing interests}

The authors declare that they have no competing interests.

\section{Authors' contributions}

$\mathrm{KH}$ performed the post mortem examination, grouped the data, and drafted the manuscript. $\mathrm{AB}$ was responsible for the trace element analyses and results, and also contributed in writing the manuscript. MSA performed the clinical observations and collection of samples. The parasitological examination of faecal samples was carried at Section for Parasitology, Norwegian School of Veterinary Science. All authors read and approved the final manuscript.

\section{Acknowledgements}

We are grateful to the owners of the herd, J.B. Ugland and H. Støyl, for their co-operation which made this study possible. Appreciation is also expressed to Thor Waaler for performance of the chemical analyses.

\section{References}

I. Radostits OM, Gay CC, Hinchcliff KW, Constable PD: Veterinary Medicine I0th edition. London: Saunders Elsevier, Edinburgh; 2007.

2. Clark RG, Hepburn JD: Deer liver and serum copper levels. Surveillance 1986, I 3: I I-I4.

3. Wilson PR: Bodyweight and serum copper concentrations of farmed red deer stags following oral copper oxide wire administration. N Z Vet J 1989, 37:94-97.

4. Fyffe Jj: Serum copper concentrations and clinical signs in red deer (Cervus elaphus Serum) during drought in central Victoria. Austral Vet J 1996, 73:188-191.

5. Wilson PR, Grace ND: A review of tissue reference values used to assess the trace element status of farmed red deer (Cervus elaphus). N Z Vet J 200I, 49: I26-I32.

6. Barlow RM, Butler E): An ataxic condition in red deer (Cervus elaphus). J Comp Path 1964, 74:5 19-529.

7. Wilson PR, Orr MB, Key EL: Enzootic ataxia in red deer. $N Z$ Vet J 1979, 27:252-254.

8. Thompson KG, Audigè L, Arthur DG, Julian AF, Orr MB, McSporran $K D$, Wilson PR: Osteochondrosis associated with copper deficiency in young farmed red deer and wapiti $x$ red deer hybrids. N Z Vet J 1994, 42:137-I43.

9. Handeland K, Bernhoft A: Osteochondrosis associated with copper deficiency in a red deer herd in Norway. Vet Rec 2004, 1 55:676-678.

10. Knox DP, Reid HW, Peters JG: An outbreak of selenium responsive unthriftiness in farmed red deer (Cervus elaphus). Vet Rec 1987, 120:91-92.

II. Mackintosh CG, Gill J, Turner K: Selenium supplementation of young red deer (Cervus elaphus). N Z Vet J 1989, 37: I43-145.

12. Vikøren T, Bernhoft A, Waaler T, Handeland K: Liver concentrations of copper, cobalt, and selenium in wild Norwegian red deer (Cervus elaphus). J Wildl Dis 2005, 41:569-579.

13. Saxegaard F: Isolation of Mycobacterium paratuberculosis from intestinal mucosa and mesenteric lymph nodes of goats by use of selective Dubos medium. J Clin Microbiol 1985, 22:3|2-3|3

14. Bernhoft A, Waaler T, Mathiesen SD, Flåøyen A: Trace elements in reindeer from Rybatsjij Ostrov, north western Russia. Rangifer 2002, 22:67-73.

15. Handeland $K$, Flåøyen $A$ : Enzootic ataxia in a Norwegian red deer herd. Acta Vet Scand 2000, 41:329-331.
16. Peters JG: Herd health programs. In Management and Diseases of Deer 2nd edition. Edited by: Alexander TL, Buxton D. Midlothian, Scotland: Macdonald Lindsay Pindar; 1994:61-65.

17. Mackintosh CG: Deer health and disease. Acta Vet Hung 1998 , 46:38I-394.

18. Jones DG: Trace element deficiencies. In Management and Diseases of Deer 2 nd edition. Edited by: Alexander TL, Buxton D. Midlothian, Scotland: Macdonald Lindsay Pindar; 1994:182-191.

19. Castillo-Alcala F, Wilson PR, Molenaar R, Lopez-Villalobos N: Efficacy, distribution and faecal excretion of copper oxide wire particles in a novel bolus in red deer (Cervus elaphus). N Z Vet J 2007, 55:8I-86.
Publish with Biomed Central and every scientist can read your work free of charge

"BioMed Central will be the most significant development for disseminating the results of biomedical research in our lifetime. "

Sir Paul Nurse, Cancer Research UK

Your research papers will be:

- available free of charge to the entire biomedical community

- peer reviewed and published immediately upon acceptance

- cited in PubMed and archived on PubMed Central

- yours - you keep the copyright

Submit your manuscript here:

http://www.biomedcentral.com/info/publishing_adv.asp
BioMedcentral 